\title{
Histological pattern and clinical outcome of childhood malignancies in a Nigerian tertiary care centre
}

\author{
*Obiora Jude Uchendu ${ }^{1}$, Akpofure Patrick Ekpebe ${ }^{2}$
}

Sri Lanka Journal of Child Health, 2021; 50(2): 253-260

\begin{abstract}
Background: Childhood cancer is an emerging, poorly addressed public health problem in developing countries. Information on the incidence and mortality of childhood cancer is scarce in these countries, despite its relevance in decision making in health sector reforms.
\end{abstract}

Objectives: To describe the histological pattern and clinical outcome of childhood malignancies in a Nigerian tertiary care centre.

Method: This is a retrospective study of childhood cancer $(<18$ years $)$ using the age, gender, histological diagnosis and their clinical outcome from 2014 to 2019 in Delta State University Teaching Hospital (DELSUTH), using information from histopathology records and patient's case notes. Data was analysed with Microsoft Excel spreadsheet and presented in tables

Results: Fifty-eight cancer cases were managed from 2014-2019, consisting of 35 males and 23 females with age range and mean age of 8 months to 17.5 years and 7.6 years respectively. The age distribution was as follows: $<1$ years: $1.7 \% ; 1-<5$ years $29.3 \%$; $5-<10$ years $36.2 \% ; 10-<15$ years $24.1 \%$ and $15-<18$ years $8.6 \%$. The major histological types encountered with their corresponding incidence are nephroblastoma $(20.7 \%)$, leukaemia $(13.8 \%)$, yolk sac tumour (10.3\%), rhabdomyosarcoma $\quad(8.6 \%)$, neuroblastoma $(6.9 \%)$, osteosarcoma $(6.9 \%)$, retinoblastoma $(6.9 \%)$, Burkitt lymphoma (5.2\%), liver cancer (5.2\%), Hodgkin lymphoma (5.2\%)

\footnotetext{
${ }_{1}^{1}$ Senior Lecturer, Department of Histopathology, Delta State University, Nigeria and Honorary Consultant, Delta State University Teaching Hospital, Nigeria, ${ }^{2}$ Academician from Nigeria with a passion for paediatric oncology

*Correspondence: ojlinksent@yahoo.com
}

D https://orcid.org/0000-0001-5432-1342 (Keceived on 13 May 2020: Accepted after revision on 19 June 2020)

The authors declare that there are no conflicts of interest

Personal funding was used for the project.

Open Access Article published under the Creative Commons Attribution CC-BY (c) (i) License and non-Hodgkin lymphoma (5.2\%). Mortality and treatment default rate were $31 \%$ and $19 \%$ respectively.

Conclusions: This study was an overview of childhood cancer in Delta State, Nigeria. There was male predominance, with maximum cases in the 510 year age group. Nephroblastoma, leukaemia, yolk sac tumour and rhabdomyosarcoma were the common malignancies. There was excessive mortality, high default rate and poor outcomes.

DOI: http://dx.doi.org/10.4038/sljch.v50i2.9566

(Keywords: Childhood cancer, mortality, histopathology)

\section{Introduction}

Child health is often regarded as major indicator of the health of a Nation ${ }^{1}$. Earlier studies in Africa have often incriminated infectious diseases as the major cause of childhood morbidity and mortality ${ }^{2}$. With success achieved from immunization, increasing access to healthcare and improved socio-economic condition, cancer is gradually taking a conspicuous position as a major cause of morbidity and mortality in these countries ${ }^{3,4}$. Across the globe, cancer is the second leading cause of childhood death after accident, with about 300,000 new cancer cases diagnosed yearly among children of $0-18$ years $^{5}$. About $90 \%$ of these childhood cancers are found in low and middle income countries of the world, where approximately $90 \%$ of world children are domiciled $^{6}$. The magnitude of the problem is better appreciated with the realization that $41 \%$ of the African population consist of children ${ }^{7}$. While the chances of surviving cancer among these children living in developed countries is about $80-90 \%$, children living in developing countries have about $20 \%$ chance of surviving cancer ${ }^{4}$.

While the incidence of childhood cancer in developed countries is well understood, such is hampered in sub-Sahara Africa by its illmaintained cancer registry and inherent poor record keeping ${ }^{6}$. Most of what we know about childhood cancer incidence in Nigerian literary space is derived from hospital-based studies, where the results were presented as the number of new cases per annum, a statistics that has shown huge geographical variation. The epidemiology of 
childhood cancer in Delta State, Nigeria, has not been elucidated. Such information is important for comparative studies. It will also guide policy makers in designing framework for cancer preventive and therapeutic intervention. We therefore present data from a tertiary care centre in Delta state with emphasis on histological pattern and treatment outcome.

\section{Objectives}

To describe the histological pattern and clinical outcome of childhood malignancies in a Nigerian tertiary care centre.

\section{Method}

Study setting: Delta State University Teaching Hospital (DELSUTH) is a tertiary care facility with 189 bed spaces. It has a well-staffed paediatric department which manages all patients below the age of 18 years. It also has a pathology department with facilities for bone marrow and tissue histology diagnosis and other basic diagnostic investigations. Immunohistochemistry and molecular studies are currently not available in its pathology laboratory. Magnetic resonance imaging (MRI) and computer tomography (CT) are also available. The hospital does not have radiotherapy service to treat children with malignancies.

Study design: This is a descriptive study that is based on histopathologically confirmed cases of paediatric cancer in DELSUTH, Delta State, Nigeria. All surgical samples submitted to the histopathology department were subjected to routine processing, embedding, microtoming and staining with haematoxylin and eosin stains.
Specialized histopathology stains were also used when necessary. The clinical outcomes of patients which were documented from the patients' case notes, were used for this study.

Inclusion criteria: The age, gender and histological diagnosis of children with cancer from $1^{\text {st }}$ January 2014 to $31^{\text {st }}$ December 2019 for patients below the age of 18 years were included in the analysis

Exclusion criteria: Cases with inconclusive diagnosis and those with missing histopathology results or case folders were excluded from the study.

Ethical issues: Ethical approval was obtained from the Institutional Ethics Committee of Delta State University, Abraka. Delta State, Nigeria (No. HREC/PAN/2019/063/0345). Written informed consent was obtained from the parents.

Statistical analysis: These results were analyzed using Microsoft Excel spreadsheet (Microsoft Cooperation, 2007) and the statistics summarized in tables.

\section{Results}

A total of 60 paediatric cancer cases were encountered during the study period. One of the cases had inconclusive diagnosis while one of the patient's case notes not could not be found. Fiftyeight cancer cases therefore met the inclusion criteria, giving a mean of about 10 cancer cases per annum. These patients consisted of $35(60.3 \%)$ males and $23(39.7 \%)$ females with a mean age of 7.6 years and a male to female ratio of $1.5: 1$. The age and gender distribution of childhood cancer cases is shown in table I.

Table 1: Age at diagnosis and gender-wise distribution of childhood cancers

\begin{tabular}{|l|c|c|c|c|}
\hline \multirow{2}{*}{ Age range (years) } & \multicolumn{2}{|c|}{ Number of cases } & \multirow{2}{*}{ Total } \\
\cline { 2 - 4 } & Males (M) & Females (F) & M:F ratio & \\
\hline$<1$ & 0 & 1 & $0: 1$ & $01(01.7 \%)$ \\
\hline $1-<5$ & $14(40.0 \%)$ & $03(13.0 \%)$ & $4.7: 1$ & $17(29.3 \%)$ \\
\hline $5-<10$ & $12(34.3 \%)$ & $09(39.1 \%)$ & $1.3: 1$ & $21(36.2 \%)$ \\
\hline $10-<15$ & $06(17.1 \%)$ & $08(34.8 \%)$ & $1: 1.3$ & $14(24.1 \%)$ \\
\hline$\geq 15$ & $03(08.6 \%)$ & $02(08.7 \%)$ & $1.5: 1$ & $05(08.6 \%)$ \\
\hline Total & $35(100 \%)$ & $23(100 \%)$ & $1.5: 1$ & $58(100 \%)$ \\
\hline
\end{tabular}

Table 2 shows the age distribution of the various histological types of childhood cancers. In infancy, only one case, a retinoblastoma, was encountered. Among patients between the ages of 1-4 years, the histological types encountered included nephroblastoma [07 (41\%)], retinoblastoma [03 $(17.7 \%)]$, embryonal rhabdomyosarcoma [02 $(11.8 \%)]$, yolk sac tumour (YST) [02 (11.8\%)] and one case $(05.9 \%)$ each of leukaemia, liver cancer and neuroblastoma. Among patients between 5-10 years, there were $05(23.8 \%)$ cases of nephroblastoma, $03(14.3 \%)$ cases of leukaemia, 02 $(09.5 \%)$ cases each of embryonal rhabdomyosarcoma, Hodgkin lymphoma (HL), neuroblastoma, non-Hodgkin lymphoma (NHL) and YST and a case (04.8\%) each of Burkitt lymphoma and brain tumour. Cases between 10-14 years included 03 cases of acute lymphoblastic leukaemia (ALL), 02 cases of Burkitt lymphoma, liver cancer, osteosarcoma and YST, and one case of alveolar rhabdomyosarcoma, liposarcoma and neuroblastoma. Malignancies involving patients of $\geq 15$ years included 5 cases one case each of leukaemia, HL, NHL, osteosacoma and squamous cell carcinoma (SCC).

Details of the gender distribution of the histological types of cancer are shown in table 3 . 
Table 2: Age variation of histological types of childhood cancers

\begin{tabular}{|c|c|c|c|c|c|c|c|}
\hline Cancer group & Type of cancer & $\begin{array}{c}<1 \\
\text { year }\end{array}$ & $\begin{array}{l}1-<5 \\
\text { year }\end{array}$ & $\begin{array}{l}5-<10 \\
\text { years }\end{array}$ & $\begin{array}{c}10-<15 \\
\text { years }\end{array}$ & $\begin{array}{c}15-<18 \\
\text { years }\end{array}$ & $\begin{array}{l}\text { Total } \\
\text { (\%) }\end{array}$ \\
\hline Leukaemia / lymphoma & Leukaemia & & 01 & 03 & 03 & 01 & $08(13.8)$ \\
\hline Sarcoma & Alveolar rhabdomyosarcoma & & & & 01 & & $01(01.7)$ \\
\hline Leukaemia / lymphoma & Burkitt & & & 01 & 02 & & $03(05.2)$ \\
\hline \multirow[t]{3}{*}{ Sarcoma } & Embryonal rhabdomyosarcoma & & 02 & 02 & & & $04(06.9)$ \\
\hline & Brain tumour & & & 01 & & & $01(01.7)$ \\
\hline & Liver cancer & & 01 & & 02 & & $03(05.2)$ \\
\hline Leukaemia / lymphoma & Hodgkin lymphoma & & & 02 & & 01 & $03(05.2)$ \\
\hline Sarcoma & Liposarcoma & & & & 01 & & $01(01.7)$ \\
\hline Blastoma & Nephroblastoma & & 07 & 05 & & & $12(20.7)$ \\
\hline Blastoma & Neuroblastoma & & 01 & 02 & 01 & & $04(06.9)$ \\
\hline Leukaemia / lymphoma & Non-Hodgkin lymphoma & & & 02 & & 01 & $03(05.2)$ \\
\hline Sarcoma & Osteosarcoma & & & 01 & 02 & 01 & $04(06.9)$ \\
\hline Blastoma & Retinoblastoma & 01 & 03 & & & & $04(06.9)$ \\
\hline Carcinoma & Squamous cell carcinoma & & & & & 01 & $01(01.7)$ \\
\hline \multirow[t]{2}{*}{ Germ cell } & Yoke sac tumour & & 02 & 02 & 02 & & $06(10.3)$ \\
\hline & Total & 01 & 17 & 21 & 14 & 05 & $58(100)$ \\
\hline
\end{tabular}

Table 3: Gender distribution of histological types of childhood cancer

\begin{tabular}{|l|c|c|c|}
\hline \multicolumn{1}{|c|}{ Histologic type } & Male (M) & Female (F) & M:F ratio \\
\hline Acute lymphoblastic leukaemia & 02 & 06 & $1: 3$ \\
\hline Alveolar rhabdomyosarcoma & 01 & 0 & $1: 2$ \\
\hline Burkitt & 01 & 02 & $1: 1$ \\
\hline Embryonal rhabdomyosarcoma & 02 & 02 & \\
\hline Brain tumour & 01 & 0 & $2: 1$ \\
\hline Liver cancer & 03 & 0 & $5: 1$ \\
\hline Hodgkin lymphoma & 02 & 0 & $1: 1$ \\
\hline Liposarcoma & 01 & 02 & $1: 2$ \\
\hline Nephroblastoma & 10 & 02 & $3: 1$ \\
\hline Neuroblastoma & 02 & 02 & $3: 1$ \\
\hline Non-Hodgkin lymphoma & 01 & 01 & \\
\hline Osteosarcoma & 03 & 01 & $1: 2$ \\
\hline Retinoblastoma & 03 & 0 & \\
\hline Squamous cell carcinoma & 01 & 04 & \\
\hline Yolk sac tumour & 02 & 23 & \\
\hline Total & 35 & & \\
\hline
\end{tabular}

Male preponderance was observed among HL, nephroblastoma, osteosarcoma, retinoblastoma, alveolar rhabdomyosarcoma, brain tumour, and squamous cell carcinoma while female preponderance was noted among ALL, Burkitt lymphoma, NHL and YST.

The clinical outcome was categorized into 5 groups as shown in table 4.

Table 4: Clinical outcome of childhood cancers in Delta State

\begin{tabular}{|c|c|c|c|c|c|c|}
\hline \multirow[t]{2}{*}{ Histologic type } & \multicolumn{6}{|c|}{ Clinical outcome } \\
\hline & Died & $\begin{array}{l}\text { Discharged against } \\
\text { medical advice }\end{array}$ & $\begin{array}{l}\text { Lost on } \\
\text { follow-up }\end{array}$ & $\begin{array}{l}\text { Completed } \\
\text { treatment }\end{array}$ & $\begin{array}{l}\text { On } \\
\text { chemotherapy }\end{array}$ & Referred \\
\hline Acute lymphoblastic leukaemia & 05 & 01 & & & & 02 \\
\hline Alveolar rhabdomyosarcoma & & & & 01 & & \\
\hline Burkitt & & & & 03 & & \\
\hline Embryonal rhabdomyosarcoma & 02 & & & 02 & & \\
\hline Brain tumour & & 01 & & & & \\
\hline Liver cancer & 02 & & & & & 01 \\
\hline Hodgkin lymphoma & & 01 & 01 & & & 01 \\
\hline Liposarcoma & & & 01 & & & \\
\hline Nephroblastoma & 04 & & & 07 & 01 & \\
\hline Neuroblastoma & & & 01 & 02 & 01 & \\
\hline Non-Hodgkin lymphoma & & & 01 & 02 & & \\
\hline Osteosarcoma & 02 & 01 & 01 & & & \\
\hline Retinoblastoma & & & & 04 & & \\
\hline Squamous cell carcinoma & & & 01 & & & \\
\hline Yolk sac tumour & 03 & & 01 & 01 & 01 & \\
\hline Total & $18(31 \%)$ & $04(06.9 \%)$ & $07(12.1 \%)$ & $22(37.9 \%)$ & $03(05.2 \%)$ & $04(06.9 \%)$ \\
\hline
\end{tabular}


Cases on referral, currently on chemotherapy, completed treatment, lost on follow-up, discharged on request of the family and those that died were $04(06.9 \%), 03(05.2 \%), 22(37.9 \%)), 07(12.1 \%)$, $04(6.9 \%)$ and $18(31 \%)$ cases respectively.

\section{Discussion}

In this study, childhood cancers accounted for $8.4 \%$ of the 689 cancer cases observed in this study. Our report is however higher than the $4.8 \%$, and $5.6 \%$ reported in Ilorin, in North Central Nigeria ${ }^{8}$, and Zaria $^{9}$ respectively, but lower than the $9.1 \%, 10 \%$, and $12.5 \%$ reported in $\mathrm{Kano}^{10}$, Jos ${ }^{11}$, and Ibadan ${ }^{12}$ respectively. At international level, our observation is higher than the $4.3 \%$ reported in Pakistan ${ }^{13}$, 1.64.8 reported in India ${ }^{14}$, and 2\% reported among Europeans and Americans ${ }^{15}$. This reflects the wide geographical variation in cancer incidence, which may be attributed to possible differences in genetic predisposition, largely unidentified environmental exposure (including in-utero exposure) and population structure $^{16}$.

The study documented a mean annual rate of 9.7 cases per year; and with the exclusion of the leukaemias, it amounted to 8.3 solid malignancies per year. This is higher than the 7 cases per annum reported in Sagamu ${ }^{17}$ and 9.2 cases per annum reported in Abuja ${ }^{18}$, but lower than the 9.9 cases per annum in Ilorin ${ }^{8}, 10.5$ cases annually in $\mathrm{Uyo}^{19}, 12$ cases per annum in Calabar $^{20}, 29$ cases per annum in $\mathrm{Enugu}^{21}, 53.3$ cases per annum in Zaria ${ }^{22}$ and $104.5 /$ annum in Ibadan $^{23}$. It is our view that the centres with the highest number of cases were those that were equipped with radiotherapy services, and that the higher figures may have been contributed by referral cases from other centres. In general, there is marked variation in number of cancer cases encountered in these hospital-based studies in Nigeria. The differences may be influenced by health seeking behaviour of the population served by the centres and differences in the age range of patients included in those studies. This statistical method is prone to error and duplication and also makes comparative analysis with reports from developed countries difficult, as most of their reports are not population-based. The advantage of population-based studies cannot be over-emphasized.

The results showed that more males had cancer than females with a male to female ratio of $1.5: 1$. This is a consistent global phenomenon ${ }^{14}$, although this observation may be further amplified by the cultural belief in this region that a male child is superior to his female counterpart ${ }^{24}$. This invariably results in gender bias towards health seeking behaviour. Our gender discrepancy is higher than the male to female ratio of 1.2:1 reported in Zaria ${ }^{9}$ and Port Harcourt ${ }^{25}$, 1.3:1 in Uyo ${ }^{19}$, Calabar ${ }^{20}$, and
$\mathrm{Jos}^{26}, 1.4: 1$ in Zaria ${ }^{22}$ and Ibadan $^{23}$ but lower than 1.7:1 in Abuja ${ }^{18}, 2: 1$ in Ilorin ${ }^{8}$, and 2.4:1 in IleIf $^{27}$. Distinctively however, in a study in Lagos, in Western Nigeria, Soyemi SS, et $a l^{28}$ reported an equal gender distribution of childhood cancer. In most developed countries, a mean male to female ratio of $1.2: 1$ has been documented ${ }^{14}$. This variation is even more striking with the different histological types. In our study, the striking male dominance was among nephroblastoma, osteosarcoma and retinoblastoma. In resource-rich countries, slight female predominance is seen among nephroblastoma, osteosarcoma, germ cell tumours and retinoblastoma ${ }^{14}$.

Only one cancer case was observed at infancy, accounting for $1.7 \%$ of the cases. As a general view, cancer is uncommon below the first year of life. Our cancer incidence among infants is lower than $2.3 \%, 3.6 \%, 5 \%$ and $6.3 \%$ reported in Zaria ${ }^{22}$, Uyo $^{19}$, Port Harcourt ${ }^{25}$ and Enugu ${ }^{21}$ respectively. The difference may be as a result of delay in presentation of the cases to the study centre. The age group 5-10 was the most affected, accounting for $36.2 \%$ of the cases. Similarly, maximum number of cases was reported among same agegroup in Uyo ${ }^{19}$, Enugu ${ }^{21}$, Owerri ${ }^{29}$, Cotde voure ${ }^{30}$ and India ${ }^{31}$. This is at variance with reports at Sagamu $^{17}$, Zaira ${ }^{22}$ and Port Harcourt ${ }^{25}$, where the maximum number of cancer occurred below the age of 5 years. This may however be a reflection of differences in healthcare seeking behaviour.

The top four causes of childhood cancers in our study (in descending order) are nephroblastoma, leukaemia, YST and rhabdomyosarcoma. These were followed with equal incidence by neuroblastoma, osteosarcoma and retinoblastoma. Our report however shows a striking variation with the report from other geographical regions. In Nigerian literary space, Burkitt lymphoma dominates other childhood cancers and has been reported as the most common childhood tumour in Uyo $^{19}$, Ile-Ife ${ }^{17}$, Ilorin ${ }^{8}$, Calabar ${ }^{20}$, Port Harcourt ${ }^{32}$, and Sagamu, Nigeria ${ }^{17}$. The high incidence of Burkitt lymphoma was attributed to endemic malaria and Ebstein Barr virus infection ${ }^{33}$. Our study centre, however shares the same geography but paradoxically, a low rate of Burkitt lymphoma. Low rate of Burkitt lymphoma was also observed by Akinsete $\mathrm{AM}$, et $a l^{34}$ in a recent study in Lagos, Nigeria. These difference calls for further studies.

Our report was similar to the report from Owerri, South Eastern Nigeria, where the leading solid childhood cancers were nephroblastoma followed in succession by rhabdomyosarcoma and neuroblastoma ${ }^{29}$. On the other hand, Tanko in Jos observed that rhabdomyosarcoma is the most common solid childhood malignancy ${ }^{26}$. In Lagos, 
Akinsete $\mathrm{AM}$, et $a l^{34}$ reported that leukaemia was the most common childhood cancer, followed in succession by retinoblastoma and nephroblastoma, while in Kano, retinoblastoma was the most common malignancy, followed by Burkitt lymphoma ${ }^{10}$. In the latter, the study centre served as a major diagnostic facility for an Eye specialist centre in that region, probably explaining the high number of eye cancer cases encountered in the centre. In North Africa, the most common malignancies in succession are leukaemia, central nervous system (CNS) tumours, and nephroblastoma or neuroblastoma ${ }^{35}$. In India, leukaemia is the most common childhood cancer ${ }^{14}$. In Europe and USA, leukaemia, brain tumours and lymphoma (in succession) are the most common childhood cancers ${ }^{14,36}$. Rarity of brain tumours is expected in developing countries and may be due to lack of manpower and equipment to have access to the brain, resulting in under-diagnosis of such cases. The reason for the high rate of nephroblastoma in our centre is not clear. We can only think that there are possible genetic differences which are worth elucidating. Interestingly, it is the $2^{\text {nd }}$ most common malignancy in $\mathrm{Uyo}^{19}$ and $\mathrm{Calabar}^{20}$, both in the same geopolitical region of Nigeria, and these areas are the oil-rich regions of Nigeria.

About $31 \%$ of the patients died during the course of treatment. Our mortality rate parallels the $32.2 \%$ observed in Zaria ${ }^{22}$, is lower than the $43.3 \%$, 45.5\% and 59\% reported in Port Harcourt ${ }^{25}$, Lagos ${ }^{34}$ and Ibadan $^{37}$ respectively, but higher than the $21.4 \%$ and $21.7 \%$ reported in $\mathrm{Uyo}^{19}$ and Abuja ${ }^{18}$ respectively. The 5-year survival for childhood cancer across Africa has been relatively low and amounting to $5 \%, 34 \%$ and $70 \%$ for Côte d'Ivoire, Egypt and South Africa respectively ${ }^{35}$. In developed countries, the 5-year survival of patients with cancer is about $80 \%{ }^{36}$. The striking higher mortality in our environment is due to many factors such as late presentation, poverty, ignorance, lack of social support, poorly trained manpower, infrastructure deficit, inconsistent drug supply, and unavailability of blood and blood products, lack of health insurance coverage and above all poor government funding of the health sector ${ }^{7,35}$.

In this study, we encountered a default rate of $19 \%$ which will no doubt impact on clinical outcome and mortality. These decisions are no doubt influenced by ignorance and poverty. Our default rate is however lower than the $25 \%, 33 \%$ and $67.8 \%$ observed in Lagos ${ }^{34}$, Port Harcourt ${ }^{35}$, Uyo ${ }^{19}$, Nigeria respectively. Reasons for not completing treatment would include dissatisfaction with quality of care, financial constraints, ignorance and inability to cope with long stay in the hospital ${ }^{7,34,35}$.
Referral rate in our centre is $7.1 \%$. Referral rate as far as we are concerned should be considered as an index of hospital performance, although there may be other reasons such as proximity to where the patient lives. There is need for the paediatric management team of DELSUTH to appraise the issue, identify missing links and collaborate with hospital management to deal with it accordingly. This may not be unrelated to deficits in man-power, physical infrastructure and quality of care, in relation to other tertiary centres in our neighborhood.

The limitation of this study is that it is a single institutional study and may therefore not be an exact picture of the population statistic. The strength on the other hand, is that the diagnoses are histologically confirmed. While we hope that someday, a central population based cancer registrar will be put in place in Delta State, the information in this report will remain the only valid document on childhood cancer in this region.

\section{Conclusions}

This study was an overview of childhood cancer in Delta State, Nigeria. There was male predominance, with maximum cases in the 5-10 year age group. Nephroblastoma, leukaemia, yolk sac tumour and rhabdomyosarcoma were the common malignancies. There was excessive mortality, high default rate and poor outcomes.

\section{References}

1. Kuo AA, Thomas PA, Chilton LA, Mascola L, AAP Council On Community Pediatrics, AAP Section on Epidemiology, Public Health, And Evidence. Paediatricians and Public Health: optimizing the health and well-being of the nation's children. Pediatrics 2018; 141(2): e20173848.

https://doi.org/10.1542/peds.2017-3848

PMid: 29358481

2. Ezeonwu BU, Chima OU, Oguonu T, Ikefuna AN, Nwafor I. Morbidity and mortality pattern of childhood illnesses seen at the Children Emergency Unit of Federal Medical Centre, Asaba, Nigeria. Annals of Medical and Health Science Research 2014; 4(3): 239-S244.

https://doi.org/10.4103/2141-9248.141966 PMid: 25364596 PMCid: PMC4212384

3. Sloan FK, Gelband H. Cancer control opportunities in low- and middle-income countries. Committee on Cancer Control in Low- and Middle-countries Board on Global Health. The National Academies 
Press; 2007. Available at: https://www.ncbi.nlm.nih.gov/books/NBK 54030/

4. Force LM. The global burden of childhood and adolescent cancer in 2017: an analysis of the Global Burden of Disease Study 2017. Lancet Oncology 2019; 20: 1211-25. https://doi.org/10.1016/S14702045(19)30 339-0

5. Steliarova-Foucher E, Colombet $\mathrm{M}$, Ries LAG, Moreno F, Dolya A, Bray F, et al. International incidence of childhood cancer, 2001-10: A population-based registry study. Lancet Oncology 2017; 18(6): 719-31.

https://doi.org/10.1016/S14702045(17)30 186-9

6. Haileamlak A. The challenge of childhood cancer in developing countries. Ethiopian Journal of Health Sciences 2016; 26(3): 199-200.

https://doi.org/10.4314/ejhs.v26i3.1

PMid: 27358539 PMCid: PMC4913186

7. Akinsete AM, Odugbemi BA, Ogundowole GE, Anene-Nzelu UU, Temiye E, Akinsulie A. Paediatric oncology in Nigeria: A panoramic view. Journal of Global Oncology 2019; 5:1-7. https://doi.org/10.1200/JGO.18.00231

PMid: 31268812 PMCid: PMC6690627

8. Babatunde AS, Gobir AA, Adeboye MAN, Adebayo-Oloko A, Durotoye IA. Pattern of childhood malignancies in Ilorin, Nigeria: Challenges and strategies for management in a tertiary health institution. Bangladesh Journal of Medical Science 2015; 14(3):241-6. https://doi.org/10.3329/bjms.v14i3.18450

9. Samaila MO. Malignant tumors of childhood in Zaria. African Journal of Paediatric Surgery 2009; 6(1): 19-23. https://doi.org/10.4103/0189-6725.48570

PMid: 19661660

10. Ochichia O, Gwarso AK, Gwarzo D. Paediatric malignancies in Kano, Northern Nigeria. World Journal of Pediatrics 2012; 8(3): 235-9.

https://doi.org/10.1007/s12519-012-03633

PMid: 22886196
11. Na'anlep MT, Echejoh GO, Manasseh NA, Mandong MB, Uba AF. Paediatric solid tumours in Nigerian children: A changing pattern? African Journal of Paediatric Surgery 2009; 6(1):7. https://doi.org/10.4103/0189-6725.48567 PMid: 19661657

12. Williams AO. Tumours of childhood in Ibadan, Nigeria. Cancer 1975; 36:370-8. https://doi.org/10.1002/10970142(197508) 36:2<370::AIDCNCR2820360212>3.0.C $\mathrm{O} ; 2-\mathrm{K}$

13. Jamal S, Mamoon N, Mushtaq S, Luqman M. Pattern of childhood malignancies: Study of 922 cases at Armed Forces Institute of Pathology (AFIP), Rawalpindi, Pakistan. Asian Pacific Journal of Cancer Prevention 2006; 7:420-2.

14. Arora RS, Eden TO, Kapoor G. Epidemiology of childhood cancer in India. Indian Journal of Cancer 2009; 46: 264-73.

https://doi.org/10.4103/0019-509X.55546 PMid: 19749456

15. Maitra A. Diseases of Infancy and Childhood. In Kumar V, Abbas AK, Aster JC. Robbins and Cotran Pathologic Basis of Disease 9ed. Philadelphia: Elsevier Saunders; 2015.p.473.

16. Chow EJ, Puumala SE, Mueller BA, Carozza SE, Fox EE, Horel S, et al. Childhood cancer in relation to parental race and ethnicity: a 5-state pooled analysis. Cancer 2010; 116:3045-53. https://doi.org/10.1002/cncr.25099 PMid: 20564410 PMCid: PMC2903004

17. Agboola AOJ, Adekanmbi FA, Musa AA, Sotimehin AS, Deji-Agboola AM, Shonubi AMO, et al. Pattern of childhood malignant tumors in a teaching hospital in south-western Nigeria. Medical Journal of Australia 2009; 190(1): 12-4. https://doi.org/10.5694/j.13265377.2009.t b02254.x

PMid: 19120001

18. Offiong UM .Childhood malignancies in University of Abuja Teaching Hospital Gwagwalada, Abuja, Nigeria. Nigerian Journal of Paediatrics 2012; 39(2):60-2. https://doi.org/10.4314/njp.v39i2.4 
19. Eno-Obong EU, Enobong EI. Childhood cancers in a referral hospital in southsouth Nigeria: a review of the spectrum and outcome of treatment. Pan African Medical Journal 2015; 22:325.

https://doi.org/10.11604/pamj.2015.22.32 5.6990

PMid: 26977233 PMCid: PMC4769810

20. Ekanem IA, Asindi AA, Ekwere PD, Ikpatt NW, Khalil MI. Malignant childhood tumours in Calabar, Nigeria. African Journal of Medicine and Medical Sciences 1992; 21(2): 63-9.

21. Ekenze SO, Ekwunife H, Eze BI, Ikefuna A, Amah CC, Emodi IJ The burden of paediatric malignant solid tumours in a developing country. Journal of Tropical Pediatrics 2010; 56(2):111-4. https://doi.org/10.1093/tropej/fmp075 PMid: 19656843

22. Ahmad HR, Faruk JA, Abdullahi M, Olorunkooba AA, Ishaku $\mathrm{H}$, Abdullahi $\mathrm{FL}$, et al. Pattern and outcomes of childhood malignancies at Ahmadubello university teaching hospital, Zaria. SubSaharan African Journal of Medicine 2016; 3(3):1.

https://doi.org/10.4103/2384-5147.190836

23. Akang EEU. Tumours of childhood in Ibadan, Nigeria. Pediatric Pathology \& Laboratory Medicine 1996; 16: 791-800. https://doi.org/10.1080/155138196091693 05

https://doi.org/10.1016/S14702045(08)70 175-X

24. Makama GA. Patriarchy and gender inequality in Nigeria: the way forward. European Scientific Journal 2013; 9(17): 115-44.

25. Eke GC, Akani NA. Outcome of childhood malignancies at the University of Port Harcourt Teaching Hospital: a call for implementation of palliative care. African Health Sciences 2016; 16(1):7582.

https://doi.org/10.4314/ahs.v16i1.10

PMid: 27358616 PMCid: PMC4915401

26. Tanko NM, Echejoh GO, Manasseh NA, Mandong MB, Uba AF. Paediatric solid tumours in Nigerian children. A changing pattern? African Journal of Paediatric Surgery 2009; 13(6): 7-10.

https://doi.org/10.4103/0189-6725.48567

PMid: 19661657

27. Shehu UA, Adegoke SA, Abdulsalam U, Ibrahim M, Oyelami OA, Adeodu OO. Pattern of childhood malignant, tumours in two tertiary teaching, hospitals in Nigeria: comparative study. Nigerian Journal of Paediatrics 2013; 40: 175 - 8.

28. Soyemi SS, Osuoji RI, Obafunwa JO, Oyewole OO, Sanni AD. The spectrum of childhood malignant tumours in a tertiary healthcare institution. World Journal of Epidemiology and Cancer Prevention 2014; 3(6): 47-50.

29. Nnadi GI, Egejuru RO, Uchendu OJ. Childhood malignant tumours in owerri; a histopathological review. International Journal of Forensic Medical Investigation 2017; 2(2)19-24.

https://doi.org/10.21816/ijfmi.v2i2.47

30. Yao JJA, Couitchere L, Atimere Y, Kone $\mathrm{D}$, Azagoh-Kouadio R, Oulai MS, et al. Childhood Cancer in Côte d'Ivoire, 1995 2004: Challenges and Hopes. South African Medical Journal 2012; 103(2):113-5.

https://doi.org/10.7196/SAMJ.6365

PMid: 23374305

31. Malik FR, Tahir A, Bashir H, Akhtar P. Spectrum of paediatric malignancies. Journal of Rawalpindi Medical College 2012; 16:37-9.

32. Seleye-Fubara D, Akani NA. Solid malignancies in children and adolescents: experience at the University of Port Harcourt Teaching Hospital. Nigerian Journal of Paediatrics 2004; 31(2):43-7. https://doi.org/10.4314/njp.v31i2.12088

33. Parkin DM, Sitas F, Chirenje M, Stein L, Abratt R, Wabinga H. Part I: Cancer in Indigenous Africans: burden, distribution, and trends. Lancet Oncology 2008; 9:68392.

34. Akinsete AM, Awofeso OM, Akere ZA, Akinsulie AO, Temiye EA. Pattern of presentation, treatment, and determinants of outcome of paediatric oncology cases at 
a tertiary institution in Lagos. Journal of Clinical Science 2018; 15:136-9.

https://doi.org/10.4103/jcls.jcls_15_18

35. Hadley LGP, Rouma BS, Saad-Eldin Y. Challenge of paediatric oncology in Africa. Seminars in Pediatric Surgery 2012; $21(2): 136-41$.

https://doi.org/10.1053/j.sempedsurg.2012 .01 .006

PMid: 22475119
36. Kaatsch P. Epidemiology of childhood cancer. Cancer Treatment Reviews 2010; 36: $277-85$.

https://doi.org/10.1016/j.ctrv.2010.02.003

PMid: 20231056

37. Brown BJ, Bamgboye EA, Sodeinde O. Causes of death in childhood cancer at the department of paediatrics, University College Hospital, Ibadan, Nigeria. African Journal of Medical Sciences 2008; 37: 713. 